\section{Ordforklaringer}

Presynaptiske nevroner: Avsendercellene for signaler mellom to nerveceller. Nerveceller kommuniserer først og fremst over synapser - spalter mellom to nerver - der kjemikalier eller nevrotransmittere skilles ut fra den ene cellen, og binder seg til den andre. Avsendercellene kalles presynaptiske, og mottakercellene postsynaptiske.

Glutamat: Den vanligste nevrotransmitter brukt i sentralnervesystemet. Glutamat binder seg til og aktiverer bestemte reseptor- eller transportermolekyler på nerveceller og utløser elektriske responser i disse.

\title{
Kommunikasjon mellom nerveceller i netthinnen
}

\author{
Studier av levende nerveceller fra rotteøyne gir ny innsikt i hvordan \\ ulike typer nerveceller i netthinnen kommuniserer og genererer \\ synsinntrykk i dunkel belysning.
}

Synssansen er en av våre mest komplekse sanser og den spiller en avgjørende rolle for vår interaksjon med miljøet rundt oss. Svein Harald Mørkve har undersøkt hvordan cellene i netthinnen kommuniserer.

- Netthinnen omdanner lysimpulser til elektriske signaler ved hjelp av spesialiserte nerveceller. Signalene prosesseres gjennom kretser av ulike typer nerveceller og koder

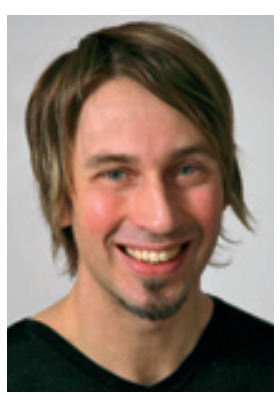

Svein Harald Mørkve. Foto Anne Sidsel Herdlevær synsinntrykk som videresendes til hjernen. Vi har undersøkt signaloverføringen som gir synsinntrykk når belysningen er dunkel, og har blant annet sett spesielt på hvordan glutamattransportere på bestemte presynaptiske nevroner fungerer. Vi har vist at glutamat som brukes for å sende signaler over den synaptiske spalten påvirker membranpotensialet til avsendercellen og inhiberer denne. Glutamat frisatt i synapsen «renner» over og påvirker også signaloverføringen mellom naboceller. Dette er helt ny kunnskap som har vakt en viss oppsikt, sier Mørkve.

Han har utviklet metoder for å registrere elektrisk aktivitet i utløpere av en bestemt type nervecelle. Resultatene bygger på forsøk hvor bitte små elektroder er festet på levende nerveceller for å registrere strøm, og registrering av strøm som utløses når reseptorene $i$ frie biter av cellemembranen fra cellene aktiveres.

Mørkve forsvarte avhandlingen Synaptic transmission between rod bipolar cells and amacrine cells in the mammalian retina ved Universitetet i Bergen 20.3. 2009.

\section{Anne Forus}

anneforu@online.no

Tidsskriftet
Reinnleggelse: Hospitalisering av pasienter som er utskrevet fra sykehus av ulike grunner og som må legges inn på nytt. I denne sammenheng er det snakk om de ikke-planlagte gjeninnnleggelsene som kommer innen en måned etter utskrivning.

Se oversikt over doktoravhandlinger i seksjonen Oss imellom på side 1303
Tips oss gjerne om doktoravhandlinger på tidsskriftet@legeforeningen.no

\section{Kortere liggetid - flere reinnleggelser}

\section{Pasienter som blir lagt inn i sykehus der liggetiden er kort og gjen- nomstrømningen høy, har større risiko for snarlig reinnleggelse.}

Det er en av konklusjonene i Torhild Heggestads avhandling Hospital readmissions and the distribution of health care. Analyses of Norwegian national register data. Krav om økt produktivitet har påvirket sykehusenes praksis, og innsatsstyrt finansiering (ISF) gir også incentiv til flere kortere sykehusopphold. Heggestad har bl.a. undersøkt om dette kan ha ført til en høyere andel ikke-planlagte reinnleggelser i somatiske og psykiatriske sykehus. Datamaterialet er hentet fra de nasjonale registrene. Avhandlingen viser at behovet for forbedret datakvalitet er stort, særlig for det psykiatriske registeret.

I perioden 2002-06 gikk liggetiden i norske sykehus ned fra 5,6 dager til 4,8 dager, samtidig med økt dagbehandling. I samme periode økte andelen ikkeplanlagte reinnleggelser med $28 \%$.

- Pasientenes sykdomstilstand, alvor- lighetsgrad og funksjonsnivå har også stor betydning for utfallet, noe det tas hensyn til i modellene. Det er imidlertid en utfordring å måle og definere de reinnleggelsene som har sammenheng med tidligere opphold, sier Heggestad.

Flest eldre pasienter blir reinnlagt. Oppfølgingen etter utskriving og samhandlingen mellom sykehus og kommune er av stor betydning, og kan forhindre en del av reinnleggelsene, mener Heggestad.

- Når man vet hvilke pasienter som er mest utsatt, kan sykehusene sammen med kommunene gjøre en mer målrettet og langsiktig innsats.

Heggestad disputerte for ph.d.-graden 2.4. 2009 ved Universitetet i Bergen.

\section{Eline Feiring}

eline.feiring@legeforeningen.no

Tidsskriftet 